\title{
PEMBELAJARAN AGAMA ISLAM KONTEKSTUAL DENGAN PHOTO ESSAYS DALAM PRAKTIK MICROTEACHING
}

\author{
Nurwanto $^{1}$, Naufal Ahmad Rijalul Alam ${ }^{2}$ \\ ${ }^{1}$ Fakultas Agama Islam Universitas Muhammadiyah Yogyakarta, Email : nurwanto@umy.ac.id \\ ${ }^{2}$ Fakultas Agama Islam Universitas Muhammadiyah Yogyakarta, Email : \\ naufal.ahmad@umy.ac.id
}

\begin{abstract}
ABSTRAK
Tulisan ini menginvestigasi desain pembelajaran mahasiswa dalam kelas microteaching dengan menggunakan photo essay (PE). Sebagaimana diketahui, pelatihan pembelajaran yang inovatif bagi calon guru Pendidikan Agama Islam (PAI) merupakan kebutuhan utama agar mereka mampu mendesain dan menerapkannya dalam tanggung jawab profesinya di masa depan. Di antara metode dan sumber belajar inovatif yang perlu diterapkan adalah photo essay agar pembelajaran lebih konstruktif dan kontekstual. Penelitian ini adalah studi kasus dengan menempatkan kelas microteaching di Prodi PAI FAI UMY sebagai unit analisisnya. Data dikumpulkan melalui FGD, dokumentasi dan observasi. Melalui analisis konten atas dokumen Rencana Pelaksanaan Pembelajaran (RPP) dan karya PE, serta analisis induktif melalui FGD dan observasi atas praktek mengajar siswa, hasil riset ini disajikan dalam bentuk tabel, foto dan narasi. Hasil penelitian menunjukkan bahwa pertama, di dalam sejumlah RPP sesuai Kurikulum 2013, PE dicantumkan baik sebagai metode, model maupun sumber belajar. Di dalamnya PE digunakan dalam dua tahap pertama pembelajaran saintifik yakni mengamati dan menanya. Namun, PE ternyata bukan satu-satunya metode dan sumber belajar dalam desain RPP karena terdapat kombinasi metode dan sumber belajar lainnya. Sementara itu, sebagian PE memuat unsur kedalaman narasi, koneksi emosi, kekuatan nilai individual, orisinal dan kontekstual karena dialami praktikan secara langsung. Kedua, praktikan menerapkan ragam pembelajaran di kelas. Ada praktikan yang menggunakan PE sebagai suplemen informasi bagi siswa dan, yang kedua, PE yang disusun hanya disajikan di akhir pembelajaran. Cara yang ketiga adalah komentar atas foto-foto dilakukan secara kolaboratif antara siswa secara individual maupun kelompok dan guru. Desain dan praktik PE dalam pembelajaran PAI ini diindikasikan mendukung pembelajaran konstruktivistik dan konstekstual sesuai kebutuhan guru di masa depan.
\end{abstract}

Kata-kata kunci : Photo Essay; Microteaching; Pendidikan Agama Islam; Rencana Pembelajaran

\begin{abstract}
This writing investigates several teaching designs using photo essays (PEs) produced by students taking microteaching. As commonly known, innovative trainings for those future teachers have been a pivotal phase in order for them to have capability of both designing and applying their professional instructions in future. One of the joyful types of learning resources that can be promoted is PEs endorsing more constructive and contextual instructions. This research is a case study placing a microteaching class as an analysis unit in which data have been collected through a focus group discussion, documentation and observation. By using a content analysis on practitioners' teaching plans and PEs, and an inductive analysis over their discussions and classrooms' practices, the result of this study is shown in the form of tables, photoes and explanations. First, those teaching plans, fitting into the 2013 curriculum, variously take PEs as methods, models as well as learning resources. In this documents, PEs have been dominantly put in the first two scientific approaches, that is observing and asking. However,
\end{abstract}




\section{Islãmadîna}

JURNAL PEMIKIRAN ISLAM

Volume 19, No. 2, September $2018: 1-26$

PEs seem not to be the only one method or learning resource set up, it is because there are other ones combined. Relating to the contents, some PEs studied contain aspects such as analytical narratives, emotional connections, individual-oriented values, originality and contextualization. Second, the students generally apply various ways of their teaching in using their PEs. There are those applying the PEs as complementary information for their audience, and, on the other hand, there are the students just reading and elaborating their PEs in the end of their instructions. The third way is that PEs are collaboratively commented by either the microteaching pratitioners or the audience, individually or in groups. It indicates that the design and implementation of these PEs help the microteaching practitioners to shape their constructive and contextual instructions considerably relevant to the need of future teachers.

Keywords: Photo Essay; Microteaching; Islamic Religious Education; Teaching Plans. 


\section{PENDAHULUAN}

Inovasi pembelajaran bagi calon tenaga pendidik telah menjadi kebutuhan. Hal ini karena, di masa depan, tenaga pendidik akan menghadapi masyarakat belajar yang multi-perspektif, berbasis teknologi dan serba digital sehingga pergeseran desain pembelajaran pun mulai terjadi dari yang bersifat konvensional menjadi inovatif dan dinamis (Prastowo, 2012: 13). Atas dasar ini, tanpa penyesuaian teknologi dalam sistem penyiapan pendidikan dan training bagi calon tenaga pendidik ini, keberadaan pendidik dalam proses pembelajaran akan semakin tertinggal dan lemah dari sisi keterampilan yang diperlukan (Miarso, 2005: 19-29). Oleh karena itu, melalui pendidikan bagi calon guru (pre-service training), mahasiswa dilatih agar mampu memahami hingga menciptakan teknologi atau produk-produk instruksionalnya.

Sebagai calon tenaga guru di masa depan, para mahasiswa yang belajar di Lembaga Pendidikan dan Tenaga Pendidikan (LPTK) secara umum, dan secara khusus di Program Studi Pendidikan Agama Islam (PAI) Universitas Muhammadiyah Yogyakarta (UMY) yang menjadi unit telaah dalam artikel ini, wajib menempuh modul Praktek Pembelajaran Mikro (Panduan Akademik $U M Y$ 2017) yang relevan dengan teknologi pembelajaran yang terbarukan. Modul ini diharapkan dapat menjadi forum belajar antar teman (peer learning) di bawah bimbingan dosen, yang secara fundamental diharapkan dapat mengondisikan mereka untuk dekat dengan sistem pembelajaran yang kreatif, aktif, menyenangkan dan kontekstual, baik berkaitan dengan materi, metode, media atau sistem evaluasinya (Widoyoko, 2009: 10). Dengan demikian, melalui proses ini diharapkan mahasiswa dapat mengalami proses belajar untuk dapat mengajar dan mengelola pembelajaran itu sendiri.

Berdasarkan observasi praktek microteaching dalam beberapa tahun akademik terakhir ini, mahasiswa sering mengalami stagnasi untuk berkreasi dan berinovasi, yang dimulai dari sistem perencanaan hingga praktek mengajar mata pelajaran PAI. Padahal, banyak sekali sumber belajar, baik yang bersifat kepustakaan maupun eksperiensial yang dapat dimanfaatkan agar praktek mengajarnya efektif. Dari sisi kebijakan nasional, pembelajaran PAI sebenarnya didorong untuk menerapkan multimedia approach (Nurwanto dan Cusack, 2017: 165-166) serta dikombinasikan dengan berbagai pilihan metode. Namun, dalam kenyataannya, tidak sedikit mahasiswa yang masih menerapkan metode ceramah secara dominan atau ragu untuk menerapkan suatu model atau metode pembelajaran yang lebih inovatif dalam kelas pembelajaran mikro. Kebutuhan terhadap pendekatan pembelajaran yang variatif ini juga diharapkan dapat memecah sekedar pendekatan doktiner yang selama ini disinyalir sangat 


\section{Islãmadîna \\ JURNAL PEMIKIRAN ISLAM}

Volume 19, No. 2, September $2018: 1-26$

dominan dalam pengajaran agama (Barness dan Wright, 2006; Kassem dan Murphy, 2009). Oleh karenanya, para mahasiswa sebagai calon guru PAI tersebut perlu dibimbing untuk mendemonstrasikan desain mengajar yang lebih efektif.

Dari berbagai cara penyajian materi pembelajaran, esai foto (photo essay) merupakan salah satu desain instruksional yang sangat praktis dengan memanfaatkan foto baik cetak maupun digital untuk menggambarkan, mengisahkan atau menjelaskan suatu peristiwa, pengalaman dan dinamika nyata sebagai sumber belajar. Menurut Douglis (2002: 36-37), foto esai bukanlah sekedar cerita tentang foto tetapi narasi yang lebih bersifat simbolik dan interpretif yang ditulis setelah foto-foto dikaitkan antara satu dengan yang lain dan di-display. Foto-foto tersebut dirangkai dan dikonstruksi sedemikian rupa sehingga dapat mengantarkan pada suatu pemahaman, ide dan nilai-nilai yang hendak disampaikan di kelas. Dengan mendasarkan pada sumber peristiwa yang nyata ini maka foto esai pada dasarnya mengikuti model pembelajaran kontekstual. Sebagaimana dikonseptualisasi oleh Johnson (2007: 21), contextual teaching and learning (CTL) di antaranya mengarahkan pada strategi yakni menjadikan aneka peristiwa nyata sebagai sumber belajar. Dengan mendasarkan pada pemikiran ini, desain foto esai akan dapat memperkuat bahan ajar PAI lebih dekat dengan peristiwa hidup nyata yang ada di sekeliling siswa. Pada akhirnya, foto esai ini akan menjadi sumber belajar baru yang dikonstruksi, disajikan, didiskusikan dan bahkan dikompetisikan di kelas.

Tulisan ini secara sistematis akan mengkaji berbagai teori dan telaah sebelumnya tentang PE dan dilanjutkan dengan pembahasan metode penelitiannya. Sementara itu, dalam hasil dan pembahasan, ada dua isu besar yang dipaparkan, yakni desain perencanaan pembelajaran dan produk PE yang dihasilkan praktikan microteaching, serta model implementasi PE dalam aktivitas pembelajaran. Tulisan ini diakhiri dengan kesimpulan dan saran.

\section{TINJAUAN PUSTAKA}

Kajian teoretik tentang esai foto (photo essay) di antaranya dilakukan oleh Douglis (2002: 36) yang membedakan antara picture story dan photo essay. Dia berargumen bahwa picture story (cerita gambar) hanya berupa narasi yang dikaitkan dengan gambar sedangkan narasi esai foto bersifat lebih simbolik dan interpretif (mendalam). Di samping itu, desain pertama menempatkan teks sebagai aspek pokok yang diikuti dengan foto sedangkan desain kedua menempatkan foto dan display antarfoto sebagai langkah utama yang diikuti 
dengan teks yang memaknainya.

Berkaitan dengan pemanfaatan media visual dan foto, temuan Sweetman (2009) menunjukkan bahwa visualisasi terhadap suatu peristiwa akan dapat membantu untuk mengungkap dan menginspirasi apa yang selama ini tidak disadari atau tersembunyi (habitus). Temuannya juga menekankan bahwa metode visual tidak hanya membuka apa yang ada di balik peristiwa tetapi juga apa yang selama ini tidak menjadi preferensi seseorang. Sementara itu, Burke dan Dollinger (2005), dengan menelaah 164 foto esai siswa menggunakan Pennebaker's Linguistic Inquiry and Word Count (LIWC), esai-esai autobiografis dapat menunjukkan ide atau pikiran reflektif seseorang yang kompleks. Keduanya juga menemukan bahwa esai-esai tersebut dapat menggambarkan individu-individu unik dengan mengeksplorasi pribadinya serta adanya korelasi antara social process words (SPW) dengan perasaan terhubung dengan pihak lain (connectedness) yang direpresentasikan oleh foto-foto yang menyentuh hati tentang orang lain atau dirinya dengan orang lain. Oleh karenanya, riset Sweetman (2009) serta Burke dan Dollinger (2005) tersebut memiliki kesinambungan bahwa foto dapat mengungkap apa yang tersembunyi dan yang tidak disadari serta membangun kesadaran unik dan spesifik tentang dunia sekitarnya.

Kajian lebih awal dan detail tentang fotografik dalam kaitannya dengan individualitas dan keterkaitan dengan pihak lain (relatedness) dilakukan oleh Dollinger, Preston, O’Brien dan DiLalla (1996). Dengan mengkaji 226 foto yang diesaikan oleh kelompok dewasa (young adults), mereka menemukan bahwa individualitas lebih dominan karena karakteristik responden lebih mengutamakan identitas personal daripada sosial. Individualitas tersebut memiliki korelasi dengan perkembangan ego yang lebih tinggi, kedewasaan dan nilai-nilai yang berorientasi pribadi (self-directed value). Sementara itu, individualitas yang rendah berkaitan dengan konformitas (conformity) yang kuat dan nilai-nilai kenyamanan. Oleh karena itu, para penulis menekankan pentingnya pengembangan individualitas dan relatedness yang optimal.

Pada kesempatan yang berbeda Dollinger (2002) mengonfirmasi hipotesisnya bahwa pribadi-pribadi yang atraktif dalam foto esai memiliki keterkaitan sosial yang sangat kuat. Namun, mereka yang atraktif juga tidak selalu lebih kreatif daripada responden yang kurang atraktif. Temuan Dollinger (2002) ini menunjukkan bahwa, dalam studi autofotografik ini, tampilan seseorang dalam foto dapat mewakili sikap seseorang. Namun demikian, tetap saja terdapat aspek-aspek yang misterius dari sikap seseorang dalam foto yang mewakilinya. Hal penting yang perlu disampaikan adalah bahwa foto dapat 


\section{Islãmadîna \\ JURNAL PEMIKIRAN ISLAM}

menjadi media untuk mengungkap makna dan memberi interpretasi baru dalam kaitannya dengan peristiwa baik pribadi sebagaimana riset yang dikembangkan oleh Dollinger et.at. (1996), Dollinger (2002) serta Burke dan Dollinger (2005), maupun diprediksi berkaitan dengan kehidupan sosial dan alam secara nyata.

Riset yang dilakukan ini tentu saja berkenaan dengan foto esai sebagaimana dimaknai oleh Douglis (2002), yakni konstruksi ide, pikiran, peristiwa dan pengalaman berdasarkan foto atau rangkaian foto yang dicipta dan di-display oleh praktikkan dan peers (sejawat) microteaching dalam mata pelajaran Pendidikan Agama Islam. Foto-foto tersebut dapat saja berkaitan dengan peristiwa pribadi yang berkaitan dengan dirinya sendiri maupun dunia sosial sebagaimana dalam riset-riset Dollinger et.at. (1996) dan Burke dan Dollinger (2005) di atas, maupun peristiwa alam, sosial atau budaya yang berdiri sendiri yang dikaitkan dengan isu-isu keagamaan secara umum atau keislaman secara khusus. Ini penting untuk dilakukan karena aspek-aspek doktrinal dan rasional (ta'aqquliy) dalam materi PAI akan memiliki makna kontemplatif dan fungsional-praktikal jika dikaitkan dengan dunia nyata. Oleh karena itu, esai foto ini akan memperkuat wilayah kontekstualitas pemahaman, penyelaman dan praktek beragama bagi warga belajar.

\section{KERANGKA TEORI}

\section{Pengertian Photo Essay}

Pemanfaatan foto untuk menggambarkan suatu peristiwa, secara historis, pernah dikembangkan oleh William Eugene Smith (w. 1978), seorang jurnalis foto berkebangsaan Amerika yang merekonstruksi peristiwa tragis Perang Dunia Kedua melalui rangkaian foto yang ia koleksi. Ia diklaim sebagai fotografer yang sangat empatik (Encyclopaedia Britannica, 2018). Tokoh lainnya adalah seorang environmentalis, Ansel Easton Adams (w. 1984) yang karya-karyanya kemudian direproduksi untuk kalender, buku dan internet (Turnage, 2017). Secara singkat, ini dapat dikatakan bahwa banyak peristiwa masa lalu (sejarah) dapat dikisahkan kembali melalui rangkaian foto yang ada.

Sebagaimana diungkap oleh Douglis (2002), photo essay (esai foto) merupakan esai atau narasi tentang foto atau rangkaian foto yang dipilih dan dikaitkan antara satu dengan lainnya sehingga menciptakan makna, pengetahuan dan pengalaman baru. Definisi ini senada dengan yang disampaikan Thompson dan Williams (2009: 11) yang mengatakan bahwa esai foto menceritakan sebagian besar cerita itu sendiri; bukan display foto yang hanya dikaitkan dengan sepenggal informasi atau narasi. Sedangkan 
Ward (2006) menyatakan bahwa esai foto dapat menyangkut apa saja tetapi harus mengandung tema atau keterkaitan makna, baik yang bersifat informatif, pengajaran atau bahkan sekedar hiburan. Kedudukan tema menjadi penting dalam esai foto sehingga kekuatan imajinasi dan inspirasi pembuat esai foto menjadi sedemikian penting dalam memaknai potongan atau rangkaian foto yang dipilih.

Dari aspek ketersediaan materi, pendidikan agama di antaranya sudah didesain dengan model tematik. Brown (2016), misalnya, memaparkan berbagai topik spesifik dalam pendidikan agama tentang kehidupan pribadi sampai sosial; spiritual hingga pemikiran; serta ritual hingga tradisi keagamaan. Pada intinya, kajian tentang agama dapat didekati dari berbagai tema spesifik yang berkaitan dengan kenyataan sehari-hari. Sedangkan dalam konteks Indonesia, Kurikulum 2013 saat ini juga di antaranya dikembangkan dengan model tematik sehingga memungkinkan guru dan siswa menelaah secara lintas bahan kajian atau mata pelajaran. Oleh karena itu, esai-esai foto dapat diproduksi dan ditampilkan dengan menggunakan tema-tema dalam pendidikan agama pada umumnya dan PAI secara khusus dengan mengambil peristiwa-peristiwa kontekstual yang siswa alami dan ketahui.

2. Prosedur Pembuatan dan Presentasi Photo Essay

Secara umum, desain esai foto dapat dikelompokkan ke dalam beberapa tahap atau aspek. Menurut Ward (2006), ada tiga tahap dalam mendesain esai foto yakni pengambilan gambar, penulisan narasi (narration), perekaman (recording) dan penyajian slide (projection). Sedangkan Thompson dan Williams (2009: 14-19) menekankan pada aspek pengambilan gambar yang dianggap paling penting, menjelaskan gambar yang telah dihasilkan, memaknai secara lebih mendalam terhadap uraian yang telah dibuat dan menyusun timelines rangkaian foto (misalnya suatu kisah kronologis) agar dapat di-display dan dipresentasikan dengan baik dan publik atau warga belajar dapat mengerti alur esai foto dengan mudah. Oleh karena itu, tahapan dan aspek-aspek yang dikemukakan oleh Ward, Thompson dan Williams tersebut akan dikombinasi sesuai kebutuhan analisis dalam penelitian ini.

Dengan mengambil intisari tulisan Thompson dan Williams (2009: 11-19) serta Ward (2006), pembelajaran dengan esai foto paling tidak meliputi beberapa langkah sebagai berikut: 1) menentukan tema photo essay berdasarkan silabus mata pelajaran; 2) mengambil objek foto sesuai sesuai 
dengan tema dengan teknik fotografi yang dimiliki dan/atau disesuaikan dengan kamera/smartphone yang digunakan (misalnya: zoom-in, zoom out, pencahayaan, landscape, portrait, dan sebagainya); 3) melakukan brainstorming dan diskusi tentang makna dan narasi foto yang telah diseleksi/dipilih, yang di antaranya dapat dilakukan dengan cara: (a) mengembangkan pemaknaan foto melalui sejumlah pertanyaan; (b) menarasikannya secara rinci; (c) menguraikan sebanyak mungkin informasi yang sesuai; (d) berspekulasi tentang simbol-simbol yang mungkin bisa dimaknai; dan (e) mengaitkan satu gambar dengan gambar yang lain; serta bagian terkahir atau 3) menyajikan esai foto dalam format buku atau poster ataupun mempresentasikannya dengan format ppt (power point) yang dapat dikombinasikan dengan audio (bila diperlukan) serta mendiskusikannya di kelas. Keempat tahapan ini mencerminkan penyusunan desain (rencana) dan implementasinya dalam pembelajaran di kelas.

3. Signifikansi PE: Konstruktivisme dan Pembelajaran Kontekstual

Pembelajaran dengan esai-esai foto akan sejalan dengan filsafat konstruktivisme apabila menempatkan siswa/mahasiswa sebagai subjek pembelajaran. Ini berarti bahwa yang mendiskusikan, menentukan dan memproduksi pengetahuan dan pengalaman melalui narasi foto adalah siswa/mahasiswa. Kebutuhan terhadap pengetahuan/pengalaman yang dikonstruk oleh warga belajar ini diperlukan karena mereka mesti mengalami proses secara langsung dan intensif tentang bagaimana suatu informasi itu diperoleh. Hal ini tentu saja berbeda dengan falsafah bahwa pengetahuan itu sekedar ditransmisikan atau diterimakan (knowledge received) yakni bahwa pengetahuan itu pada awalnya dimiliki oleh seseorang yang kemudian ditransfer kepada orang lain (dalam hal ini adalah siswa/mahasiswa). Keberadaan 'orang lain' ini bersifat pasif karena hanya menerima informasi saja (Ellis, 1998: 25). Oleh karena itu, melalui aktivitas ini diharapkan siswa/mahasiswa dapat menjadi subjek belajar yang aktif dan proaktif dalam menggali dan menyajikan informasi yang diperoleh dari pengalamannya.

Makna penting PE lainnya adalah bahwa sumber belajar ini dapat mengondisikan warga belajar dekat dengan konteks dan situasi yang berkembang di sekitarnya. Ada sebuah pendekatan pembelajaran yang berbasis pada konteks dan nilai, misalnya, Living Values Education (LVE). Pendekatan pendidikan karakter ini menempatkan persoalan sehari-hari dan kebutuhan nilai positif sebagai fokus untuk menumbuhkan potensi setiap warga belajar sehingga mereka akan dapat menghadapi tantangan masa depan yang kompleks (Tillman dan Colomina, 2004: 170). Untuk memenuhi 
kebutuhan ini, pembelajaran semestinya juga dilakukan secara partisipatif (Munawar-Rachman (Ed.), 2015: xix). Begitu juga dengan pembelajaran dengan PE. Siswa diharapkan lekat dengan daily life (kehidupan keseharian) dan berpartisipasi aktif dalam memaknai dan merekonstruksi peristiwa di sekitarnya dengan cermat dan mendalam agar nilai-nilai yang ada di balik peristiwa dapat terungkap dan berguna bagi kehidupannya. Pada aspek ini, misalnya, temuan Burke dan Dollinger (2005) mengenai connectedness atau perasaan terhubung dengan orang lain yang mengalami peristiwa yang difotografikan, dapat menjadi sumber pengetahuan dan pengalaman baru. Oleh karena itu, desain PE dengan pembelajaran yang mampu menggerakan warga belajar untuk berpartisipasi aktif di dalamnya adalah dua sisi yang tidak dapat dipisahkan (two sides in a coin).

\section{METODE PENELITIAN}

Penelitian ini merupakan studi kasus tentang desain dan implementasi pembelajaran Pendidikan Agama Islam dengan photo essay dengan unit analisisnya berupa kelas microteaching. Secara spesifik, riset ini mengkaji desain rencana mengajar dalam kelas microteaching yang biasa disebut dengan RPP (Rencana Pelaksanaan Pembelajaran) beserta desain atau karya berupa photo essays (PE). Lebih jauh dari itu, aktivitas pembelajaran di kelas microteaching oleh para praktikan juga diinvestigasi sehingga dapat dideskripsi dan dianalisis model implementasi PE dalam kelas tersebut. Penelitian ini dilakukan di Prodi PAI FAI UMY dalam mata kuliah Micro Teaching Semester Genap Tahun Akademik 2017/2018 yang melibatkan 1 (satu) rombongan belajar yang berjumlah 15 praktikan. Secara individual maupun kelompok mereka memilih bahan PAI, mengambil atau memilih foto, menyusun dan men-display foto-foto yang telah diesaikan tersebut serta mengajarkannya dalam kelompok microteaching. Sementara itu, data dikumpulkan melalui: 1) dokumentasi berupa RPP dan EP yang disusun mahasiswa/praktikan; 2) FGD tentang desain pembelajaran, baik RPP maupun PE; 3), serta observasi kelas microteaching. Data dalam bentuk dokumen/karya mahasiswa selanjutnya dianalisis isinya (content analysis) serta data hasil FGD dan observasi diklasifikasi dan diformulasi sebagai dasar penyusunan kategori konseptual yang berasal dari kelas microteaching (inductive analysis). Secara kualitatif, ada proses coding, sorting dan penemuan patterns (Thomas, 2009: 197) dari data yang dikumpulkan. Melalui verifikasi antarsumber data, hasil riset dianalisis, dibahas dan disajikan dalam bentuk tabel, foto dan narasi. 


\section{Islãmadîna \\ JURNAL PEMIKIRAN ISLAM}

Volume 19, No. 2, September $2018: 1-26$

\section{HASIL DAN PEMBAHASAN}

1. Desain Photo Essay dalam Persiapan Praktek Mengajar

a. Desain RPP

Sebelum para mahasiswa sebagai praktikan microteaching menyusun rencana mengajar, terlebih dahulu dilakukan penjelasan, tanya jawab dan diskusi terfokus (focus group discussion) tentang pengertian dan pemahaman mengenai photo essay (selanjutnya disingkat PE) pada dua pertemuan awal mata kuliah Microteaching. Bagi mahasiswa, PE dianggap sebagai metode yang relatif baru yang akan mereka terapkan. Meskipun demikian, beberapa di antaranya memiliki asumsi yang sama bahwa sebagai cara untuk mengajar, PE ini akan menggunakan foto sebagai sumber dan interaksi belajar di kelas. Dari FGD, ada satu kesimpulan bahwa PE tidak hanya sebagai cara bagaimana seseorang belajar aktif dan langsung dari lapangan sebagaimana perspektif konstruktivisme (Ellis, 1998: 25), namun PE juga sebagai salah satu sumber belajar itu sendiri. Sebagai sumber belajar, PE bersifat intangible (tidak tersentuh karena abstrak) karena yang dihadirkan di kelas adalah visual, kesan dan makna dari realitas yang difotografikan. Pada konteks demikian, perspektif ini memperluas manfaat FE dalam kegiatan pembelajaran.

Diskusi penting lainnya dalam pertemuan tersebut adalah apakah foto yang disajikan harus orisinal dan nyata (diambil langsung dari objek oleh mahasiswa) atau foto itu diambil dari pihak kedua sehingga bersifat sekunder, misalnya: dokumentasi sekolah, dokumentasi pribadi atau lembaga lainnya termasuk yang ada di situs internet. Secara teoretik, PE sebenarnya merekomendasikan bahwa foto itu diambil dari situasi ril yang ditemukan dan dialami oleh subjek belajar sehingga memiliki kontekstualitas yang tinggi, sebagaimana dikembangkan oleh Ward (2006) serta Thompson dan Williams (2009). Namun, sebagian mahasiswa berpendapat bahwa kontekstualitas pada Mata Pelajaran (mapel) Sejarah, misalnya, tentu saja adalah masa lalu yang mungkin telah diverfikasi dan didokumentasikan oleh seseorang atau lebih spesifiknya: sejarawan. Oleh karena itu, dalam kasus demikian, sumber sekunder yang bersifat dokumentatif seperti foto menjadi penting untuk dihadirkan kembali. Pandangan ini sepenuhnya absah dalam pengertian bahwa ada realitas/lapangan kehidupan yang tidak langsung terjangkau oleh indera subjek belajar sehingga sumber belajar itu disediakan oleh sejarawan misalnya, yang sebenarnya adalah subjek belajar masa lalu itu sendiri. Foto yang didokumentasikan oleh William Eugene Smith (fotografer PD II) 
misalnya memiliki kontekstualitas yang tinggi dibandingkan imajinasi atau spekulasi berfikir generasi sesudahnya yang tidak menyaksikan peristiwa kelam sejarah manusia itu. Oleh karena itu, penulis berargumen bahwa kontekstualitas foto dalam PE tergantung pada beberapa sudut pandang, yakni: karakteristik kontennya dan subjek yang mengalami. Aspek yang pertama menuntut kontekstualitas yang berbeda antara mapel Sejarah/Tarikh dan konten mapel lainnya yang dikonstruksi secara langsung oleh warga belajar. Sedangkan yang kedua, pengalaman pribadi yang mengalami, memiliki kontekstualitas yang lebih tinggi dibandingkan mereka yang memanfaatkan dokumentasi yang diambil atau dikonstruksi oleh pihak lainnya.

Bekal pengetahuan teoretik dan persepsional tentang PE tersebut, selanjutnya dijadikan sebagai acuan bagi mahasiswa untuk menyusun RPP. Dalam kelas microteaching ini, ada 15 (lima belas) RPP yang telah mereka hasilkan dan selanjutnya dikaji dalam studi ini. Kelima belas RPP tersebut dihasilkan setelah mahasiswa beserta dosen pengampu berdiskusi awal mengenai PE. Pada prinsipnya, RPP yang dihasilkan menggunakan format Kurikulum 2013 (K-13) yang di antaranya menekankan pada pendekatan ilmiah (scientific approach) dan student-centered learning, serta-dalam sejumlah hal-bersifat tematik (topical) yang memungkinkan materi digali dari dunia kontekstual yang mengitari siswa (lihat: Sani, 2014; Kurniawan, 2011; Mulyasa, 2014). Atas dasar ini, secara teoretik, PE dapat ditempatkan sebagai salah satu metode dan/atau sumber belajar yang dapat dikombinasikan pula dengan metode lainnya yang telah dipilih. Sebagai salah satu pendekatan dalam K-13, pendekatan saintifik mengenalkan 5 tahapan pembelajaran yang dikenal dengan $5 \mathrm{M}$, yakni: mengamati, menanya, mengumpulkan informasi, mengasosiasi/mengolah informasi dan menyajikannya (Palupi, 2016: 136; Kosasih, 2014: 19; Yani, 2014: 127-128) dalam berbagai format, bentuk dan situasi pembelajaran. Meskipun pendekatan saintifik ini bukan satu-satunya pendekatan dalam implementasi K-13, keberadaannya menjadi sedemikian penting untuk membiasakan warga belajar dalam menumbuhkan rasa ingin tahu, menyadari akan permasalahan yang ada di sekitarnya, menggali informasi yang diperlukan, mendiskusikan dan menyajikan telaahnya dalam forum pembelajaran dengan warga kelas lainnya. Tabel berikut ini menyajikan garis besar RPP yang bisa ditelaah lebih lanjut: 
Tabel 1: Garis Besar Desain Esai Foto dalam Rencana Mengajar

\begin{tabular}{|c|c|c|c|c|c|c|c|}
\hline No & $\begin{array}{l}\text { Prakti } \\
\text { kan } \\
\text { (Initial } \\
\text { s) }\end{array}$ & Mapel & Topik & Photo Esay & $\begin{array}{c}\text { Aktivitas } 5 \mathrm{M} \text { (mengamati; } \\
\text { menanya; mengumpulkan data; } \\
\text { mengasosiasi; } \\
\text { mengkomunikasikan) }\end{array}$ & Metode Lain & $\begin{array}{l}\text { Learning } \\
\text { Aids }\end{array}$ \\
\hline 1. & Hid & $\begin{array}{l}\text { Kemuha } \\
\text { mmadiya } \\
\text { han }\end{array}$ & $\begin{array}{l}\text { Majelis/Lembag } \\
\text { a }\end{array}$ & Model & Mengamati gambar dan menanya & $\begin{array}{l}\text { Small Group } \\
\text { Discussion } \\
\text { (SGD), Ceramah, } \\
\text { Demonstrasi }\end{array}$ & $\begin{array}{l}\text { LCD, } \\
\text { kertas, } \\
\text { spidol }\end{array}$ \\
\hline 2. & Alf & Tarikh & $\begin{array}{l}\text { Perkembangan } \\
\text { Agama Islam }\end{array}$ & ND & Mengamati foto dan menanya & $\begin{array}{l}\text { Cooperative } \\
\text { Learning }(\mathrm{CL}), \\
\text { Ceramah, Praktek }\end{array}$ & LCD \\
\hline 3. & Cin & $\begin{array}{l}\text { Kemuha } \\
\text { mmadiya } \\
\text { han }\end{array}$ & $\begin{array}{l}\text { Sikap } \\
\text { Muhammadiyah } \\
\text { terhadap } \\
\text { Perkembangan } \\
\text { Pendidikan } \\
\text { Islam }\end{array}$ & Metode & $\begin{array}{l}\text { Mengamati gambar yang } \\
\text { ditayangkan dan memberi } \\
\text { feedback }\end{array}$ & $\begin{array}{l}\text { Diskusi, } \\
\text { Presentasi }\end{array}$ & LCD \\
\hline 4. & Nin & $\begin{array}{l}\text { Ibadah } \\
\text { dan } \\
\text { Muamala } \\
\text { h }\end{array}$ & $\begin{array}{l}\text { Pengurusan } \\
\text { Jenazah }\end{array}$ & ND & $\begin{array}{l}\text { Mengamati gambar dan } \\
\text { menanggapi }\end{array}$ & $\begin{array}{l}\text { Ceramah, } \\
\text { Demonstrasi, } \\
\text { Contextual } \\
\text { Teaching and } \\
\text { Learning (CTL) }\end{array}$ & $\begin{array}{l}\text { LCD, } \\
\text { Perlengkap } \\
\text { an Urus } \\
\text { Jenazah }\end{array}$ \\
\hline 5. & An & $\begin{array}{l}\text { Quran } \\
\text { dan } \\
\text { Hadis }\end{array}$ & $\begin{array}{l}\text { Beban Sesuai } \\
\text { Kemampuan } \\
\text { Manusia }\end{array}$ & ND & $\begin{array}{l}\text { Menanya gambar yang } \\
\text { ditampilkan }\end{array}$ & $\begin{array}{l}\text { Ceramah, Diskusi, } \\
\text { CL, Puzzle }\end{array}$ & $\begin{array}{l}\text { LCD, Buku } \\
\text { Gambar }\end{array}$ \\
\hline 6. & Sit & $\begin{array}{l}\text { Bahasa } \\
\text { Arab }\end{array}$ & $\begin{array}{l}\text { Profesi } \\
\text { (mihnah) }\end{array}$ & Metode & ND & $\begin{array}{l}\text { Ceramah, Cerita, } \\
\text { Guessing the } \\
\text { Picture }\end{array}$ & LCD \\
\hline 7. & Mar & $\begin{array}{l}\text { Ibadah } \\
\text { dan } \\
\text { Muamala } \\
\text { h }\end{array}$ & Qurban & Model & Mengamati foto & $\begin{array}{l}\text { SGD, Ceramah, } \\
\text { Demonstrasi }\end{array}$ & $\begin{array}{l}\text { LCD, Pisau } \\
\text { mainan, } \\
\text { boneka }\end{array}$ \\
\hline 8. & Rim & $\begin{array}{l}\text { Quran } \\
\text { dan } \\
\text { Hadis }\end{array}$ & Rajin Bekerja & Metode & $\begin{array}{l}\text { Mengamati dan menanya gambar } \\
\text { yang ditayangkan }\end{array}$ & Ceramah, CL & $\begin{array}{l}\text { LCD, } \\
\text { Kertas } \\
\text { Karton }\end{array}$ \\
\hline 9. & Gal & Tarikh & $\begin{array}{l}\text { Kelahiran Nabi } \\
\text { Saw }\end{array}$ & Metode & ND & $\begin{array}{l}\text { Tanya Jawab, } \\
\text { Ceramah, CL }\end{array}$ & $\begin{array}{l}\text { LCD, } \\
\text { Spidol, } \\
\text { Kertas }\end{array}$ \\
\hline 10. & Haf & $\begin{array}{l}\text { Aqidah- } \\
\text { Akhlak }\end{array}$ & Akhlak Terpuji & ND & ND & $\begin{array}{l}\text { CL, Diskusi, } \\
\text { Demonstrasi }\end{array}$ & $\begin{array}{l}\text { LCD, } \\
\text { Sterofom, } \\
\text { Kertas } \\
\text { Warna }\end{array}$ \\
\hline 11. & Ham & $\begin{array}{l}\text { Aqidah- } \\
\text { Akhlak }\end{array}$ & $\begin{array}{l}\text { Iman Kepada } \\
\text { Kitab Suci }\end{array}$ & ND & ND & $\begin{array}{l}\text { Ceramah, Diskusi, } \\
\mathrm{Cl} \text { (Jigsaw } \\
\text { Learning) }\end{array}$ & LCD \\
\hline 12. & $\mathrm{Ag}$ & $\begin{array}{l}\text { Aqidah- } \\
\text { Akhlak }\end{array}$ & Akhlak Terpuji & ND & ND & $\begin{array}{l}\text { CL, Diskusi, } \\
\text { Demonstrasi }\end{array}$ & LCD \\
\hline 13. & Ghaf & $\begin{array}{l}\text { Aqidah- } \\
\text { Akhlak }\end{array}$ & Gigih & Metode & Mengamati foto & $\begin{array}{l}\text { Ceramah, Diskusi, } \\
\text { Student Centered } \\
\text { Learning, Inquiry }\end{array}$ & $\begin{array}{l}\text { LCD, Photo } \\
\text { Essay }\end{array}$ \\
\hline 14. & Sam & $\begin{array}{l}\text { Ibadah } \\
\text { dan } \\
\text { Muamala } \\
\text { h }\end{array}$ & Hudud dan Zina & Metode & $\begin{array}{l}\text { Mengamati dan menanya gambar } \\
\text { yang ditayangkan }\end{array}$ & $\mathrm{CL}$ & $\begin{array}{l}\text { LCD. Photo } \\
\text { Essay }\end{array}$ \\
\hline 15. & $\mathrm{NN}$ & $\begin{array}{l}\text { Aqidah- } \\
\text { Akhlak }\end{array}$ & $\begin{array}{l}\text { Iman Kepada } \\
\text { Rasul }\end{array}$ & ND & ND & $\begin{array}{l}\text { Ceramah, Inquiry, } \\
\text { Quantum } \\
\text { Learning, } \\
\text { Tanya-Jawab }\end{array}$ & $\begin{array}{l}\text { LCD, } \\
\text { Gambar, } \\
\text { Video }\end{array}$ \\
\hline
\end{tabular}

Sumber: RPP Mahasiswa Semester Genap Tahun Akademik 2017/2018

Keterangan: $N D=$ No Data; $N N=$ No Name 
Dari tabel 1 tersebut, ada beberapa isu pokok yang dapat ditelaah lebih lanjut yakni: 1) keberadaan PE sebagai model atau metode; 2) aktivitas $5 \mathrm{M}$ sebagai implementasi scientific approach; 3) variasi metode dan isu integrasi metodologis; dan 4) isu media, sumber belajar serta alat bantu pembelajaran. Terlepas dari keragaman Sub-Mapel seperti Aqidah-Akhlak, Tarikh, Quran-Hadis dan Bahasa Arab dalam Mapel yang disebut Al-Islam, Kemuhammadiyahan dan Bahasa Arab (ISMUBA), salah satu nama khas Mapel di Perguruan Muhammadiyah, PE pada umumnya dipersepsi oleh praktikan microteaching sebagai metode pembelajaran. Lazimnya yang dicantumkan oleh mahasiswa dari sekitar 15 RPP adalah istilah pendekatan, model, strategi dan metode. Terlepas dari definisi konseptual yang bermacam-macam, metode merupakan ruang lingkup spesifik dibandingkan konsep lainnya yang merujuk pada cara praktis untuk mengantarkan materi; untuk mencapai tujuan pembelajaran; atau untuk memfasilitasi proses belajar peserta didik. Definisi terakhir ini-sebagaimana direpresentasikan kata 'memfasilitasi'-seringkali secara substansial diadopsi oleh mereka yang mendukung pendekatan andragogi atau student-centered learning (SCL). Dengan menempatkan PE sebagai metode, ini jelas bahwa bagi praktikan microteaching, PE diset sebagai cara agar materi dapat dipelajari oleh warga belajar dengan efektif meskipun tentu saja seberapa tingkat efektivitasnya tidak menjadi fokus dalam penelitian ini. Di samping terma 'metode', istilah 'model' juga muncul. Dalam Concise Oxford English Dictionary (Eleventh Edition), kata 'model' ini diartikan sebagai 'sesuatu yang dijadikan sebagai contoh untuk diikuti' yang dapat berupa figur atau produk. Bila definisi ini digunakan untuk menempatkan PE dalam proses pembelajaran maka dapat dikatakan bahwa PE dapat dijadikan sebagai contoh produk yang dapat digunakan oleh siapapapun yang hendak memahami suatu objek kajian seperti Akhlak, Tarikh dan lainnya. Namun demikian, sebagai model pembelajaran, PE yang dihasilkan tentu saja tidak selalu akan menjadi rujukan selama produk tersebut tidak melahirkan wawasan yang bermakna bagi subjek belajar. Tabel 1 juga menunjukkan bahwa masih ada sebagian praktikan yang tidak mencantumkan PE baik sebagai model atau metode pembelajarannya dalam RPP.

Aspek berikutnya dari RPP adalah penjabaran pendekatan ilmiah (scientific approach). Tabel 1 menginformasikan bahwa, meskipun masih ada RPP yang tidak mencantumkan aktivitas 5 M yang berkaitan dengan $\mathrm{PE}$, terdapat sejumlah praktikan yang mendesain PE sebagai sumber belajar. 


\section{Islãmadîna

Sebagaimana diketahui, aktivitas 'mengamati' merupakan aktivitias inderawi untuk menangkap informasi yang dapat dilakukan melalui membaca, mendengar, menyimak dan melihat (tanpa atau dengan alat) sedangkan aktivitas 'menanya' merupakan aktivitas untuk mendapatkan, mengonfirmasi atau memperdalam informasi dari yang bersifat faktual hingga hipotetik (Yani, 2014: 127). Menurut Kosasih (2014: 74), objek pengamatan dapat berupa teks atau tayangan anekdot. PE yang dikonstruksi praktikan itu tampak merupakan objek belajar yang sebagian besar ditayangkan melalui power point. Sementara itu, aktivitas 'menanya' ditujukan untuk mengembangkan rasa ingin tahu peserta didik (Kosasih, 2014: 74). Ada 5 RPP yang secara eksplisit mencantumkan kegiatan 'menanya' ini. Selain itu, ada juga aktivitas 'memberi feedback' atau 'menanggapi' foto yang ditayangkan. Meskipun dalam FGD disepakati bahwa PE dapat dicantumkan dan didemonstrasikan dalam aktivitas ' $M$ ' berikutnya - terutama mengkomunikasikan hasil karya atau diskusi sehingga dapat dimengerti oleh teman kelasnya-RPP yang disusun pada umumnya masih berpusat di sekitar $2 \mathrm{M}$ yang pertama (mengamati dan menanya). Oleh karenanya, perencanaan dan demonstrasi PE yang terintegrasi dalam keseluruhan aktivitas pembelajaran belum tampak dalam RPP yang telah disusun.

Isu lainnya adalah variasi metode pembelajaran. Bagi Pollard et.al. (2008: 385), metode pembelajaran dapat berkontribusi pada suasana kelas dan pesan moral yang diharapkan. Yang pertama berkaitan dengan kelayakan siswa untuk dapat belajar (learning process) bukan sekedar menyimak materi dari guru (teaching process). Sedangkan yang kedua mencakup nilai-nilai (values) sehingga metode yang menekankan pada kompetisi individual tentu berbeda dengan metode yang berorientasi kerjasama seperti cooperative learning. Hal yang tampak dari tabel 1 adalah bahwa praktikan merencanakan pembelajaran dengan sangat bervariasi/kombinatif yang terentang dari ceramah, tanya-jawab, presentasi, diskusi hingga cooperative learning. Variasi dan pilihan metode pembelajaran tentu bersifat lentur dan sesuai kebutuhan karena sebagaimana dikatakan Cohen, Manion dan Morrison (1996: 17), kemunculan suatu rencana aksi adalah respons terhadap sistem belajar yang fleksibel (tidak kaku) termasuk pemanfaatan teknologi informasi. Dengan sendirinya, praktikan dapat memilih metode yang relevan dalam RPP yang disusunnya. Namun, ketika dikaji dalam RPP, tidak semua model atau metode yang dicantumkan diuraikan di dalam langkah-langkah 
pembelajaran. Uraian terperinci dari metode yang dipilih semestinya muncul dalam keseluruhan langkah-langkah pembelajaran karena RPP adalah panduan atau manual tentang bagaimana aktivitas pembelajaran itu dilakukan yang jika dioperasionalisasikan oleh guru yang tidak menyusun RPP itu pun pembelajaran dapat berlangsung dan mendekati proses yang diharapkan.

Isu terakhir yang dapat didiskusikan adalah media atau sumber belajar. Keseluruhan RPP memanfaatkan sarana/teknologi modern seperti LCD, video dan perangkatnya, di samping beberapa sumber atau media pembelajaran konvensional lainnya seperti kertas dan spidol serta perlengkapan lainnya sesuai tujuan spesifik, misalnya untuk mendemonstrasikan pengurusan mayat, kelas menggunakan kain kafan dan sebagainya. Sementara itu, ketika belajar tentang berkurban, sejumlah sarana seperti boneka dan pisau mainan dipersiapkan. Hal yang menarik juga adalah bahwa dari RPP yang ada, ada 2 RPP yang mencantumkan PE sebagai sumber belajar. Hal ini mengandung pengertian bahwa praktikan menempatkan PE sebagai sumber informasi bagi peserta didik untuk memahami suatu objek kajian. Dalam situasi ini, PE merupakan produk/karya yang di(re)konstruksi oleh peserta didik sehingga menjadi pengetahuan (baru) bagi masyarakat yang memanfaatkannya. Inilah sebenarnya puncak dari aktivitas kognitif yang paling tinggi yakni kreasi/inovasi atau C(cognition)-6 sebagaimana revisi taksonomi Benjamin Bloom oleh Anderson dan Krathwohl (2001). Pendek kata, PE di sini bukan lagi sekedar sebagai metode dan langkah-langkah pembelajaran namun produk kognitif yang dihasilkan oleh peserta didik sehingga menjadi pengalaman dan pengetahuan baru.

b. Produk Photo Essay dalam Pembelajaran

Sebagaimana tampak dalam tabel 1 , setiap sub-mapel memuat sejumlah pokok bahasan atau topik. Dari sekian topik/pokok bahasan, tidak semua praktikan menyiapkan PE sebagai model atau sumber belajar. Bahkan ada beberapa topik PE yang disiapkan secara khusus karena menyesuaikan dengan minat praktikan sehingga dalam perjalanannya sebagian dari mereka mengubah pokok bahasan atau topik RPP. Kondisi ini merupakan dinamika dalam menyusun RPP di satu sisi dan PE di sisi yang lain untuk menampilkan sumber belajar yang informatif bagi peserta didik di kelas Microteaching. Di bawah ini ada beberapa PE yang telah disiapkan dan diproduksi oleh praktikan yang dapat dikaji dari beberapa hal sebagai berikut: 1) ketercukupannya sebagai PE (mendalam/simbolik vs deskriptif) 


\section{Islãmadîna

dengan mengacu pada konsep Douglis (2002) maupun Thompson dan Williams (2009); 2) representasi konten yang dapat berkaitan dengan telaah Sweetman (2009) tentang habitus (kondisi/cara/habit seseorang atau kelompok yang membentuk aspek fisik, pikiran dan mentalnya); Burke dan Dollinger (2005) tentang connectedness (perasaan terhubung dengan orang lain); Dollinger, Preston, O'Brien dan DiLalla (1996) mengenai tipe individualitas dan social relatedness seseorang; dan 3) dimensi orisinalitas dan kontekstualitasnya. Aspek yang terakhir ini merupakan telaah atas asas kesesuaiannya dengan kebutuhan faktual yang dihadapi siswa. Ketiga aspek di atas menjadi perspektif tentang bagaimana PE yang didesain oleh para praktikan memenuhi aspek-aspek yang dimaksud.

Untuk kepentingan studi ini, ada beberapa topik/bahasan PE yang dapat dianalisis. Pertama, PE dengan topik 'Perang di Era Nabi' (lihat Gambar 1). Praktikan memberikan narasi gambar sebagai berikut:

Photo Essay ini berupa peta Makkah dan Madinah yang di dalamnya merupakan gambaran hijrah Rasulullah dari Makkah ke Madinah. Adanya perpindahan atau hijrah ke Madinah tentunya disebabkan oleh beberapa faktor. Kemudian ketika sampai di Madinah Rasulullah disambut baik oleh Kaum Anshar, akan tetapi tidak dapat dipungkiri bahwa ada pihak-pihak yang tidak menyukai kedatangan Rasulullah yaitu kaum kafir, mereka secara diam-diam menyimpan kebencian kepada Rasulullah. Berawal dari kebencian tersebut kemudian muncul konflik yang pada akhirnya memicu beberapa kali peperangan.

PE ini menampilkan gambar dan narasi tentang peta wilayah Saudi Arabia terutama posisi Mekah dan Madinah sebagai jalur migrasi Nabi dan pengikutnya. Namun, peta ini tidak secara spesifik menampilkan jalur hijrah sebagaimana esainya. Sedangkan gambar kedua bukanlah foto tetapi lukisan yang menunjukkan suasana perang. Meskipun gambar ini menampilkan suasana perang, tetapi sebagai kajian Tarikh sepertinya perlu ditunjukkan pada peristiwa perang apa itu terjadi. Dalam esainya, praktikan sepertinya menekankan pada imajinasi tentang 'emosi' perang itu sendiri bukan pada di mana dan kapan itu terjadi. PE ini merepresentasikan tentang connectedness emosi (Burke dan Dollinger, 2005) pembaca/warga belajar tentang kemungkinan yang dapat dirasakan jika mengalami situasi perang yang demikian. Di sini, imajinasi dan emosi kemungkinan hadir. Gambar dalam PE itu tidak orisinal dan nyata yang dialami praktikan tetapi lebih menekankan pada konstruksi pesan/moralnya. Pesan itu berkaitan dengan potensi konflik dan perang yang dapat terjadi akibat perseteruan dan kebencian atas perbedaan sikap dan pilihan 
Gambar 1: Photo Essay Tarikh tentang Perang di Era Nabi

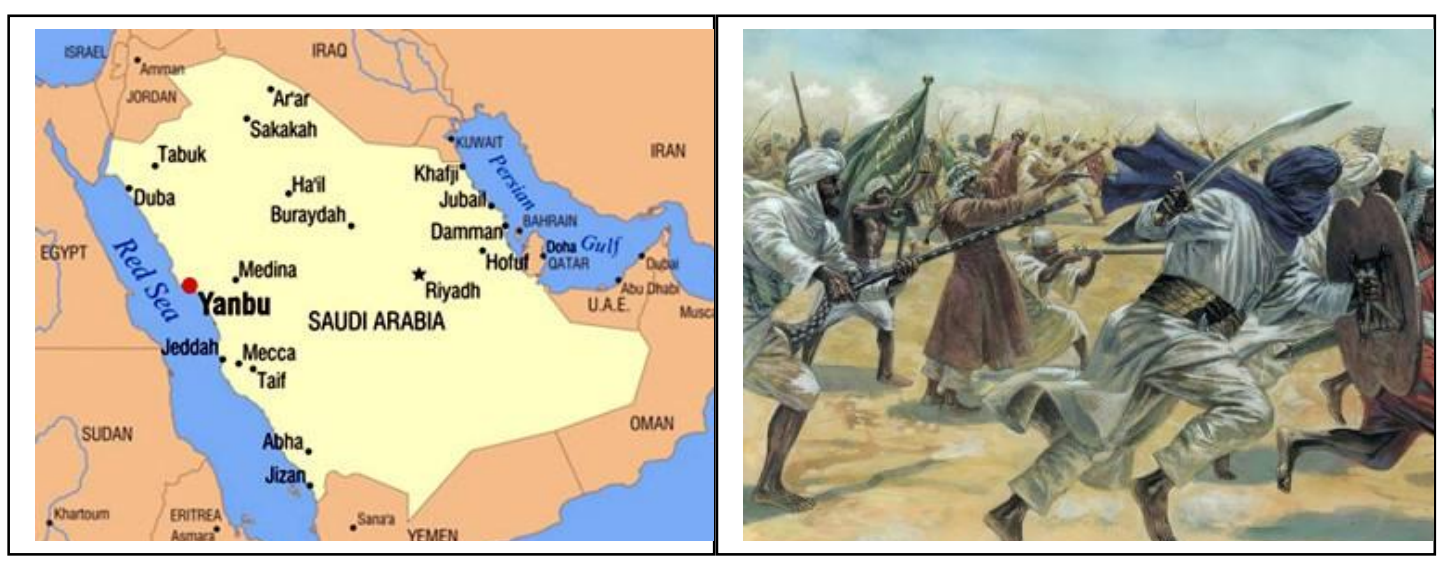

PE-2 dalam mata pelajaran Akhlak bertema 'Adab Makan'. PE ini menyajikan narasi yang mendalam, kompleks dan lebih detil dari foto yang ada tentang aktivitas di sebuah warung makan meskipun foto tidak secara eksplisit menunjukkan adab/perilaku makan itu sendiri. PE ini memiliki kekuatan pada detil narasinya; bukan pada fotonya. Berdasarkan pandangan Thompson dan Williams (2009: 14-19), fokus foto perlu dipilih kembali. Hal lainnya adalah perlu dipertimbangkan tidak hanya berupa satu foto tetapi rangkaian foto sebagaimana direkomendasikan Douglis (2002) sehingga detil peristiwa cukup terwakili dalam foto. PE ini merepresentasikan aspek social relatedness sebagaimana ditemukan Dollinger, Preston, O’Brien dan DiLalla (1996) atau habitus (Sweetman, 2009) yakni tentang bagaimana perilaku sosial bersama di warung makan dan pada saat yang sama tentang nilai yang diyakini pembuat PE (individualitas) bahwa makan dan minum ada etika utama yang perlu diterapkan. PE ini menunjukkan aktivitas yang dialami praktikan (orisinal) dan kontekstual sebagaimana peristiwanya dapat dialami juga oleh warga belajar yang lain.

PE-3 dalam kajian Ibadah dan Muamalah bertema 'Makanan dan Minuman'. PE ini mengilustrasikan dua foto dalam setting berbeda yang diikat oleh tema tentang makanan yang tidak boleh (haram) bagi orang Islam. Foto pertama menarasikan foto secara jelas dan mendalam tentang kandang babi dengan kebiasaan asupan makanan yang tidak layak. Isi narasinya memenuhi unsur emotional connectedness (Burke dan Dollinger, 2005) termasuk empati penyusunnya atas mereka yang tinggal di lingkungan peternakan itu. Sedangkan foto kedua menarasikan detil tentang pemisahan daging babi dari jenis makanan lainnya yang halal bagi orang Islam. Namun foto itu tampak tidak cukup mewakili detil ilustrasi. 


\section{Islãmadîna

Walaupun demikian, narasinya cukup jelas memuat preferensi nilai individual dan konformitas sosial (Dollinger, Preston, O’Brien dan DiLalla, 1996) Muslim tentang makanan halal yang layak dikonsumsi. PE ini menunjukkan orisinalitas dan kontekstualitas tentang peristiwa yang dialami praktikan yang disajikan di kelas.

PE-4 dalam kajian Akidah dan Akhlak dengan tema 'Iman kepada Allah' menyajikan tema iman kepada Allah, terutama pembuktian perilaku sehari-hari bahwa seseorang meyakini bahwa Allah itu ada yang selalu mengawasinya. Tiga PE yang disusun berupa rangkaian foto dari peristiwa yang berurutan yang kemudian dinarasikan menjadi penggalan peristiwa, yakni tentang ketaatan seorang muslim melalui salat, suka membantu dan kejujuran. Narasi ditulis singkat dan sederhana tapi cukup menggambarkan rangkaian foto yang ditampilkan. PE tersebut menekankan pada pesan moral tentang pentingnya habit yang positif dalam mengkonsruk mindset keimanan atau habitus (Sweetman, 2009). Penyusun menekankan pada ilustrasi sosok individual dengan preferensi nilai dan moral yang kuat (Dollinger, Preston, O’Brien dan DiLalla, 1996) tentang perilaku agamis apa yang perlu dipilih. Foto yang dirangkai sangat jelas tetapi ini yang menunjukkan bahwa foto-foto itu tampak bukanlah peristiwa natural tetapi demonstrasi perilaku yang kemudian didokumentasikan sehingga tidak orisinal dan tidak kontekstual sebagai peristiwa yang dialami langsung praktikan. Model PE seperti ini tentu saja lebih menekankan pada pesan moralnya bukan pada keotentikan peristiwanya.

PE-5 dalam kajian Al-Quran dan Al-Hadis berkaitan dengan tema pentingnya waktu dengan menampilkan dua peristiwa (dalam foto) yang saling bertolak belakang; yang pertama tentang perilaku negatif dan yang kedua positif (lihat Gambar 2). Praktikan menyusun narasi PE-nya sebagai berikut:

Foto 1 memperlihatkan beberapa remaja yang asyik bermain game di play station; yang sering tanpa memperhatikan waktu, bahkan hingga larut malam. Apa yang mereka lakukan merupakan sesuatu yang tidak baik, kerena mereka membuang-buang waktu dengan percuma. Bermain dengan tanpa melihat waktu adalah perbuatan yang tidak bermanfaat. Bermain itu lumrah bagi siapa saja tetapi harus dapat membagi waktu: kapan waktu belajar, waktu beribadah dan kegiatan lainnya. Allah SWT nyatakan dalam Q.S. Al-Ashr, bahwa orang yang menghabiskan waktu untuk hal-hal yang tidak bermanfaat itu termasuk golongan yang merugi. Sedangkan Foto 2 merupakan contoh orang yang memanfaatkan waktu dengan baik dengan jalan menegakkan ibadah 
sholat berjamaah tepat pada waktunya di masjid. Perbuatan mereka juga termasuk yang bukti keberimanan dan kesalehan.

Gambar 2: Photo Essay Al-Quran/Hadis tentang Makna Penting Waktu
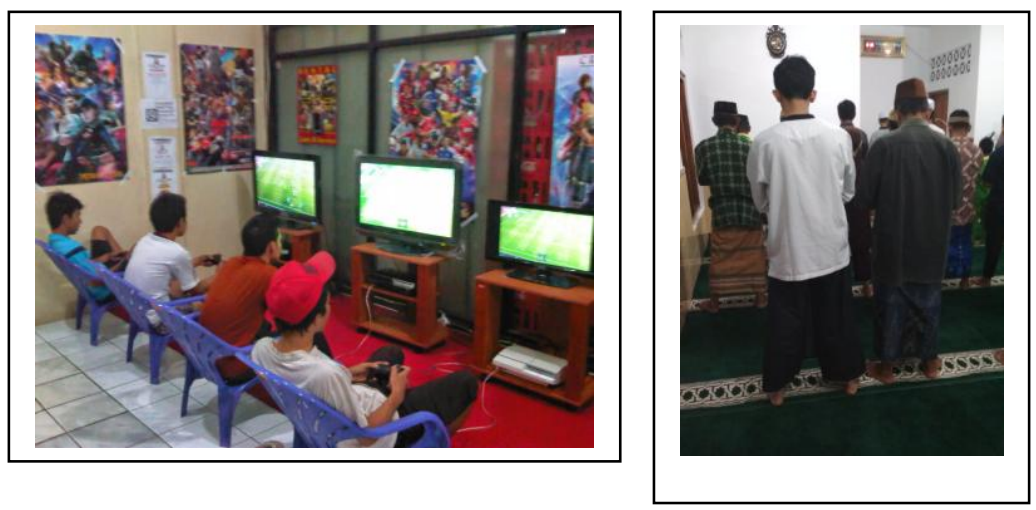

Narasi PE yang disusun di atas cukup mendalam dan simbolik yakni memaknai peristiwa dalam foto; bukan sekedar mendeskripsikan foto apa adanya. Sebagaimana dalam telaah Dollinger, Preston, O'Brien dan DiLalla (1996), PE tersebut juga menunjukkan preferensi individual terhadap nilai tertentu, apakah menggunakan waktu untuk kegiatan positif atau negatif. Dalam alam nyata, tentu tidak sesederhana dengan mengatakan bahwa kesukaan remaja pada game bukan berarti dia meninggalkan ibadah; begitu pun sebaliknya. Tetapi, penyusun juga menarasikan bahwa sangat mungkin ada kebiasaan remaja yang tidak mampu mengelola waktu untuk kegiatan-kegiatan yang positif sehingga ia terjebak pada konformitas nilai sosial yang buruk dan merugikan. Foto yang disajikan tampak orisinal dan kontekstual dari lokasi play station dan di masjid.

PE-6 dalam pelajaran bahasa Arab bertema 'Kebersamaan'. Foto-fotonya merupakan peristiwa yang berbeda-beda dalam waktu yang berbeda pula tetapi semuanya dirangkai menjadi cerita. Narasinya mendalam dan simbolik sehingga memiliki pesan nilai spesifik tentang pentingnya kebersamaan bagi manusia. Sebagaimana dinyatakan Douglis (2012), foto-foto yang dirangkai dapat memiliki makna dan pengalaman baru bagi pembaca atau warga belajar. Konten PE tampak mengarahkan warga belajar pada elemen hidup bersama yang secara kontekstual juga dialami mereka, atau diistilahkan Burke dan Dollinger (2005) sebagai connectedness dengan kondisi di mana penyusun PE mengalami peristiwa itu dan mencoba melakukan refleksi moral agar memiliki makna bagi 


\section{Islãmadîna \\ JURNAL PEMIKIRAN ISLAM}

Volume 19, No. 2, September $2018: 1-26$

pembaca/warga belajar lainnya. Secara keseluruhan, foto-foto itu menunjukkan orisinalitas karena diambil dalam setting natural dan mengandung aspek kontekstual karena dari peristiwa langsung yang dialami penyusun dan dihadirkan dalam makna emosional yang memungkinkan dekat dengan audiens.

Keenam PE yang disusun praktikan microteaching secara umum menunjukkan adanya ruang lingkup yang relatif sama dan beberapa aspek lainnya yang bersifat variatif sebagaimana dalam tabel berikut:

Tabel 2: Pemenuhan Komponen Photo Essay

\begin{tabular}{|c|c|c|c|c|c|c|c|}
\hline \multirow{2}{*}{ No. } & \multicolumn{2}{|c|}{ Tipe Narasi } & \multicolumn{3}{c|}{ Representasi Konten } & \multicolumn{2}{c|}{ Kontekstualitas } \\
\cline { 2 - 8 } & Deskriptif & $\begin{array}{c}\text { Imajinatif-Si } \\
\text { mbolik }\end{array}$ & Habitus & $\begin{array}{c}\text { (Emotional) } \\
\text { Connectedness }\end{array}$ & $\begin{array}{c}\text { Individualitas } \\
\text { (Self-directed } \\
\text { value) }\end{array}$ & Orisinal & Kontekstual \\
\hline 1 & & $*$ & $*$ & $*$ & $*$ & $*$ & $*$ \\
\hline 2 & & $*$ & $*$ & $*$ & $*$ & $*$ & $*$ \\
\hline 4 & $*$ & $*$ & & $*$ & $*$ & $*$ & $*$ \\
\hline 5 & & $*$ & $*$ & & $*$ & $*$ \\
\hline 6 & & $*$ & & $*$ & & $*$ & $*$ \\
\hline
\end{tabular}

Keterangan: tanda* menunjukan sesuai/diterapkan

Tabel 2 mengindikasikan bahwa sebagian besar PE dinarasikan secara mendalam, imajinatif dan-beberapa hal—simbolik. Narasi yang mendalam atau tidak berhenti dalam narasi deskriptif ini merupakan tipe penulisan yang direkomendasikan. Narasi-narasi yang ada juga memiliki tren membangkitkan keterikatan emosional dengan kasus atau nilai-nilai tertentu yang dipahami atau diyakini. Lebih dari itu, preferensi atau pilihan individual seorang penyusun (praktikan microteaching) terhadap nilai yang dianggap baik juga dominan. Meskipun ada beberapa gambar atau foto yang tidak orisinal tetapi ada pula foto-foto yang sangat personal dan eksperiensial atau orisinal dan kontekstual, baik yang dialami oleh penyusun PE maupun bagi warga belajar dalam proses microteaching.

2. Implementasi PE dalam Praktek Microteaching

Sebagaimana ditemukan kesesuaian maupun kelemahan, baik dalam dokumen RPP maupun dalam pemenuhan desain photo essay (PE) dari satu sisi, serta praktek mengajar mahasiswa di kelas microteaching di sisi yang lain menjadi menarik untuk diinvestigasi. Menurut Kelly (2009: 11), apa yang direncanakan dalam silabus atau RPP dapat sesuai atau tidak sesuai dengan apa yang berlangsung di kelas secara nyata (the planned versus received curriculum). Dengan demikian analisis berikut ini dikonstruksi dari asumsi oleh adanya tingkat relevansi rencana dan implementasi, dan bahkan dalam implementasinya itu sendiri sangat mungkin sesuai atau tidak sesuai 
berdasarkan kerangka konseptual pembelajaran yang diharapkan. Pembelajaran yang bercorak konstruktivistik, misalnya, saat ini dianggap sesuai dengan paradigma learner-centered dan mendukung proses ekplorasi pengetahuan yang terbuka, bukan sekedar terfokus pada guru (teacher-centered teaching authority); serta berorientasi pada 'the stimulation of child's powers' (John Dewey dalam Flinders dan Thornton, 2004: 17). Era pembelajaran abad ke-21 ini yang setidaknya diadopsi oleh Kementerian Pendidikan dan Kebudayaan Republik Indonesia bahwa guru ditempatkan sebagai tenaga pendidik yang multitasking, yakni: mendidik, mengajar, mendidik, mengarahkan, melatih, menilai dan mengevaluasi (Bab I Pasal 1 ayat 1 UU Nomor 14 Tahun 2005). Mutitugas itu tidak mungkin dapat dilakukan hanya menempatkan guru sebagai satu-satunya sumber pengetahuan tetapi guru itu sendiri sebaiknya mampu mengolah, memanfaatkan, memfasilitasi dan mengarahkan siswa untuk mengambil informasi dan pengalaman dari berbagai sumber, baik tekstual, kontekstual; dan personal maupun sosial.

Berdasarkan observasi kelas, hampir semua praktikan tidak menempatkan PE yang telah dibuatnya sebagai satu-satunya sumber informasi. Namun demikian, sesuai dengan prosedur pembelajaran saintifik, praktikan sebagai guru terlebih dahulu menyajikan foto atau gambar sehingga peers (mahasiswa lainnya) sebagai siswa dapat mengeskpresikan pendapat dan perspektifnya tentang foto yang ditampilkan. Misalnya, ketika praktikan menyampaikan bahasan 'adab makan dan minum' (lihat PE-2), pembelajaran diawali dengan gambar orang yang sedang makan di rumah makan lalu siswa diminta untuk berkomentar terhadap gambar tersebut. Berikutnya ditampilkan Q.S. Al-A'raf ayat 31 tentang adab makan dan minum. Selanjutnya siswa dibagi ke dalam 4 kelompok, yang masing-masing diberi sebuah gambar seperti gambar orang yang makan sambil duduk dan gambar piring tanpa sisa makanan yang sudah baru saja digunakan untuk makan. Dalam diskusi, siswa diminta untuk berpendapat tentang apa maksud dan hikmah dari gambar-gambar berkaitan dengan adab makan (Observasi, 13/03/2018). Pola pembelajaran seperti ini mengindikasikan bahwa PE yang disusun oleh mahasiswa/praktikan hanya menjadi suplemen bacaan karena dalam kelas, praktikan menekankan pada stimulasi gambar (tidak ada narasinya) yang selanjutnya siswa memberikan komentar.

Sementara itu, ada implementasi pembelajaran dengan PE lainnya secara berbeda. Dalam pembelajaran tentang makanan halal (lihat PE-3), 
kelas diawali dengan tadarus QS An-Nas, kemudian ditampilkan gambar babi, kambing, dan daging babi dalam freezer. Kemudian siswa diminta berkomentar tentang gambar-gambar tersebut. Selanjutnya guru memberikan pengantar materi dan membagi siswa ke dalam 3 kelompok yang memiliki sub-kajian yakni makanan halal, haram lidzatih dan haram lighairih. Dalam masing-masing kelompok, siswa diberi aneka gambar makanan halal dan haram kemudian siswa diminta untuk menempel gambar sesuai dengan sub-kajian di kelompoknya. Pada bagian akhir, guru selanjutnya menayangkan esai foto yang telah disusunnya di LCD untuk penguatan materi yang telah didiskusikan (Observasi, 13/03/2018). Di sini tampak bahwa narasi atas foto/gambar yang disusun mahasiswa/praktikan ditempatkan sebagai penguat informasi di akhir pembelajaran. Sementara itu, pada awal pembelajaran, siswa diberi keleluasaan untuk mengamati, menanya, mengumpulkan informasi, mengasosiasi/menalar dan menyajikan hasil diskusi kelompok mereka terhadap foto-foto yang ditayangkan di LCD ataupun yang dibagikan oleh guru.

Praktek mengajar lainnya adalah mahasiswa menampilkan gambar dengan meminta peserta didik memberi feedback dan, pada saat yang sama, mahasiswa juga mengutarakan narasinya. Misalnya, sesuai dengan PE-4, praktikan/mahasiswa menayangkan foto seorang laki-laki yang menjalankan sholat meskipun sibuk dengan tugas-tugasnya dan selanjutnya siswa diminta mengomentari foto tersebut. Praktikan juga ikut menambahkan narasi dan pendapatnya tentang foto yang ditayangkan (Observasi, 12/03/2018). Pola ketiga ini dapat dikatakan sebagai model interaksi ide dan narasi antara praktikan (guru) dan siswa. Dari sisi pendekatan, di samping siswa menyampaikan pendapatnya atas foto yang tersaji secara individual (individually active learning), para siswa juga memiliki kesempatan untuk berdiskusi dalam kelompok untuk mempertemukan persepsi tentang suatu gambar tertentu misal aktivitas untuk PE-3 (Observasi, 13/03/2018) sebagaimana ditekankan dalam cooperative learning tentang siswa sebagai jaringan belajar (Sharan [Ed.], 1999: x), dan bersama dengan guru, para siswa mengutarakan makna atas foto yang ditayangkan (collaborative work) seperti yang muncul dalam implementasi pembelajaran PE-4 (Observasi, 12/03/2018). Keragaman pendekatan tersebut, merupakan pilihan sekaligus variasi cara untuk memperoleh pengetahuan baru sesuai prinsip konstruktivisme dalam pembelajaran. 


\section{SIMPULAN}

Inovasi pembelajaran Agama Islam bagi mereka yang belajar di institusi pendidikan guru (teacher training) saat ini, baik dari aspek metode maupun isi, menjadi kebutuhan. Sebagaimana riset ini yang dilakukan di Prodi Pendidikan Agama Islam Fakultas Agama Islam UMY, sejumlah praktikan microteaching mendesain pembelajaran mereka dengan menggunakan esai foto (photo essay, PE) serta menerapkannya dalam kegiatan pembelajaran. Dari desain dan praktek kelas tersebut, setidaknya ada beberapa kesimpulan utama yang dapat diutarakan. Pertama, desain rencana pembelajaran atau yang disebut sebagai RPP (Rencana Pelaksanaan Pembelajaran) menempatkan PE secara bervariasi baik sebagai model, metode atau sumber belajar. Dalam desain tersebut, PE sebagian besar dituangkan dalam aktivitas mengamati dan menanya, dua tahapan pertama dari 5 tahap scientific approach sebagaimana secara formal ditetapkan dalam Kurikulum 2013. Secara konseptual, desain RPP yang ada menunjukkan bahwa keberadaan PE secara praktis akan dikombinasikan dengan metode dan media pembelajaran lainnya yang relevan. Sementara itu, PE yang diproduksi mahasiswa pada umumnya sudah mencapai tipologi PE yang mendalam dan--beberapa hal-simbolik, memuat unsur koneksi emosi penyusun dengan peristiwa atau sosial, serta memuat keyakinan individual atas nilai tertentu. Sejumlah praktikan microteaching sebagai guru juga mengambil gambar secara langsung sehingga memenuhi dimensi kontekstual dan orisinal dari foto yang ditampilkan. Kedua, di kelas, sejumlah praktikan memanfaatkan PE secara beragam. Di antaranya ada yang menggunakan PE dari praktikan (guru) sebagai suplemen informasi karena dalam aktivitas mengamati (M-1) dan menanya (M-2), praktikan hanya menyajikan foto yang selanjutnya dikomentari dan didiskusikan oleh peserta didik. Model pembelajaran yang kedua adalah PE yang disusun praktikan hanya ditayangkan di akhir pembelajaran sebagai penguat dari proses pembelajaran yang telah dilakukan. Sedangkan model terakhir adalah, secara kolaboratif, siswa dan guru memberikan komentar dan terutama praktikan menyajikan narasinya sebagai pembanding dan pelengkap informasi. Proses ini menunjukkan bahwa kontekstualisasi pembelajaran Agama Islam melalui PE cukup bervariasi melalui kegiatan individual, dialog/sharing pendapat hingga kolaborasi dalam memberi makna atas foto atau PE yang disajikan.

Penelitian kasus ini bersifat deskriptif-kualitatif yang mendasarkan datanya pada dokumen RPP dan PE (photo essays) yang dibuat oleh mahasiswa sebagai praktikan microteaching serta data observasi kelas tentang implementasi pembelajaran Agama Islam yang menggunakan PE. Riset ke 


\section{Islãmadîna \\ JURNAL PEMIKIRAN ISLAM}

depan, misalnya, bisa difokuskan pada $\mathrm{R} \& \mathrm{D}$ tentang proses penyusunan dan produk RPP atau PE sehingga setiap tahap pengembangannya dapat termonitor dan terukur berdasarkan tema atau subtema tertentu. Di samping itu, riset yang telah dilakukan ini tidak meng-assess aspek kontekstualitas materinya berdasarkan perspektif warga belajar yang mengikuti setiap microteaching. Oleh karena itu, angket, skala sikap keterkaitan (relatedness) materi PE dengan kehidupan mereka atau wawancara mendalam perlu dilakukan dalam skup penelitian lainnya di masa depan.

\section{DAFTAR PUSTAKA}

Anderson, L.W. dan Krathwohl, D.R.2001. yang berjudul: A Taxonomy for Learning, Teaching and Assessing: A Revision of Bloom's Taxonomy of Educational Objectives: Complete Edition.

Barnes, L.P. and Wright, A. 2006. Romanticism, representations of religion, and critical religious education. British Journal of Religious Education, 28 (1), pp. 65-77.

Brown, D. 2016. Religious Studies for GCSE: Philosophy and Ethics Applied to Christianity, Roman Catholicism \& Islam. Cambridge and Malden, MA: Polity

Burke, P.A. dan Dollinger, S.J. 2005. "A picture's worth a thusand words": language use in the autophotographic essay', Personality and Social Psychology Bulletin, 31(4), 536-548.

Cohen, L., Manion, L., dan Morrison, K. 1996. A Guide to Teaching Practice Fourth Edition. London: Routledge.

Tillman, D. dan Colomina, P.Q. 2004. LVEP: Panduan Pelatihan bagi Pendidik. Jakarta: Grasindo.

Concise Oxford English Dictionary (Eleventh Edition)

Dollinger, S.J., Preston, L.A., O'Brien, S.P., dan DiLalla, D.L. 1996. 'Individuality and relatedness of the self: an autophotographic study', Journal of Personality and Social Psychology, 71(6), 1268-1278.

Dollinger, S.J. 2002. 'Physical attractiveness, social connectedness and individuality: an autophotographic study', The Journal of Social Psychology, 142(1), 25-32.

Ellis, A.K. 1998. Teaching and Learning Elementary Social Studies Sixth Edition. USA: Allyn \& Bacon.

Encyclopaedia Britannica. 2018. M. Eugene Smith American Photographer. https://www.britannica.com/biography/W-Eugene-Smith diakses 19/01/2018.

Flinders, D.J. dan Thornton, S.J. (Eds.). 2004. The Curriculum Studies Reader Second Edition. New York: Routledge Falmer.

Johnson, E.B. 2007. Contextual Teaching and Learning: Menjadikan Kegiatan Belajar-Mengajar Mengasyikkan dan Bermakna. Bandung: Mizan Media Utama 
Kassem, D. dan Murphy, L. 2009. Faith schools: Diversity or division? In D. Kassem and D. Garratt (Eds) (Ch. 5, pp. 70-82). Exploring Key Issues in Education. London: Continuum.

Kelly, A.V. 2010. The Curriculum Theory and Practice Sixth Edition. London: SAGE Publications Limited.

Kosasih, E. 2014. Strategi Belajar dan Pembelajaran: Implementasi Kurikulum 2013. Bandung: Yrama Widya.

Kurniawan, D. 2011. Pembelajaran Terpadu: Teori, Praktek dan Penilaian. Bandung: Pustaka Cendikia Utama.

Miarso, Y. 2005. Menyemai Benih Teknologi Pendidikan. Jakarta: Prenada Media dan Pusat Teknologi Komunikasi dan Informasi Pendidikan Pustekkom Diknas.

Mulyasa, H.E. 2014. Pengembangan dan Implementasi Kurikulum 2013. Bandung: Remaja Rosdakarya.

Munawar-Rachman, B. (Ed.). 2015. Pendidikan Karakter: Pendidikan Menghidupkan Nilai untuk Pesantren, Madrasah dan Sekolah. Jakarta: LSAF dan ALIVE Indonesia.

N.N. 2014. Himpunan Lengkap Undang-Undang Sistem Pendidikan Nasional. Yogyakarta: Saufa.

Nurwanto dan Cusack, C.M. 2017. 'Addressing multicultural societies: lessons from religious education curriculum policy in Indonesia and England,' Journal of Religious Education, 64(3), 157-178.

Palupi, D.T. 2016. Cara Mudah Memahami Kurikulum. Surabaya: Jaring Pena.

Pollard, A. et.al. 2008. Reflective Teaching Third Edition. London: Continuum.

Prastowo, A. 2012. Panduan Kreatif Membuat Bahan Ajar Inovatif: Menciptakan Metode Pembelajaran yang Menarik dan Menyenangkan. Yogyakarta: DIVA Press.

Sani, R.A. 2014. Pembelajaran Saintifik untuk Implementasi Kurikulum 2013. Jakarta: Bumi Aksara.

Sharan, S. (Ed.). 1999. Handbook of Cooperative Learning Methods. London: Greenwood Publishing Group, Inc.

Sweetman, P. 2009. 'Revealing habitus, illuminating practice: Burdieu, photography and visual methods', The Sociological Review, 57(3), 491-511.

Thomas. G. 2009. How to Do Your Research Project: A Guide for Students in Educatin and Applied Social Sciences. London: SAGE Publications Ltd.

Thompson, S.C. dan Williams, K. 2009. Telling Stories with Photo Essays. USA: Corwin.

Turnage, W. 2017. Ansel Adams, Photographer. http://anseladams.com/ansel-adams-bio/, 19/01/2019.

Ward, S.R. 2006. 'Tips and techniques for photo essays', PSA Journal, no number, 16.

Widoyoko, S.E.P. 2009. Evaluasi Program Pembelajaran: Panduan Praktis bagi Pendidik dan Calon Pendidik. Yogyakarta: Pustaka Pelajar. 


\section{Islãmadîna}

JURNAL PEMIKIRAN ISLAM

Volume 19, No. 2, September $2018: 1-26$

Yani, A. 2014. Mindset Kurikulum 2013. Bandung: Alfabeta. 